Jurnal Administrasi Publik (Public Administration Journal), 1(1) Bulan 2018 ISSN2088-527X

(Print) ISSN2548-7787 (Online), DOI: 10.31289/iap.v11i2.5614

Jurnal Administrasi Publik (Public Administration Journal)

Available online http://ojs.uma.ac.id/index.php/jap

\title{
E-Effectiveness Musrembang's in the Development Planning Process in Medan's Denai District
}

\author{
Siti Hazzah Nur Ritonga1) ${ }^{*}$, \& Humaizi ${ }^{2)}$ \\ 1)Public Administration, Political and Social Science Faculty, Universitas Sumatera Utara, \\ Indonesia \\ 2) Communication Science, Political and Social Science Faculty, Universitas Sumatera Utara, \\ Indonesia
}

Accapted: 24 September 2021; Approved: 0esember 2021; Published: 03 Desember 2021

*Corresponding Email: sitihazzah@usu.ac.id

\begin{abstract}
In the regional development planning process, there are frequently deviations in people's aspirations. Musrenbang is a community forum for channeling aspirations in development planning. The launch of the e-musrembang application is expected to accommodate all community aspirations, allowing regional development to be more focused on the community's actual needs. This research aims to determine the efficacy of e-musrembang in development planning in Medan City and the problems or obstacles encountered when using the application. Using qualitative research methods, this study focuses on the Medan Denai District. Interviews, observation, and documentation were used as data collection techniques. Miles, Huberman, and Saldana's interactive analyses were used to analyze the data. The study's findings concluded that had not been effectively implemented the e-Musrenbang system. There is no significant difference between the achievement of the e-Musrenbang system's objectives and the implementation $b$ From the achievement of the purposes of the e-Musrenbang system, and there is no significant difference from the implementation before after the e-Musrenbang. Citizens' misunderstanding in the e-Musrenbang system is judged due to the lack of good communication between the government and its citizens. In the adaptation stage, the Kelurahan and Medan Denai Subdistrict Governments, as implementers in the use of the system, are still rigid and do not understand well the use of the eMusrenbang system.
\end{abstract}

Keywords: Effectiveness; e-Musrenbang; Regional Development Planning.

How to Cite: Ritonga, S.H.N., \& Humaizi, (2021). E-Effectiveness Musrembang's in the Development Planning Process in Medan's Denai District. Jurnal Administrasi Publik (Public Administration Journal). 11 (2): $185-196$ 


\section{INTRODUCTION}

The problem in the development planning process through the Regional Development Planning Deliberation (Musrenbang) is that many people's aspirations are not channeled in development. The main explanation for Law Number 25 of 2004 concerning the National Development Planning System explains that planning with a participatory approach is carried out by involving all stakeholders in development. Their involvement is to get aspirations and create a sense of belonging. Plans resulting from the development process are harmonized through deliberation. Aziz, Bambang, dan Khairul (2012) explained that the critical problems of implementing regional development planning are top-down. Often, strategic issues are not raised, and the mindset is always one-way.

According to Carlson (2007), The 21st century is the century of customers. This statement emphasizes that the position of society has moved to be at the top of the pyramid. So the community is the determinant for what the government does, including in terms of development.

The development planning process carried out by local governments cannot be separated from processing the community's aspirations as the primary substance in preparing regional development plans. One of the facilities provided by the government to the community to participate in regional development planning is through the implementation of Musrenbang. According to Article 1 of Law No. 25 of 2004, the Development Planning Deliberation (Musrenbang) forum for national and regional development plans. Musrenbang implementation begins at the ward/village level and progresses to the provincial level. Musrenbang, as a place to accommodate people's aspirations, emphasizes the importance of community participation in the development plan's preparation. Adisasmita (2006) tells to program
Community development is a form of bottom-up planning.

Not a few people admit that the development carried out by the local government is not under the community's needs. Tresiana \& Duadji (2016), In his research in Lampung Province, revealed that mapping the Musrenbang forum had revealed several weaknesses at almost all levels, and he also explained that at the lower level, the Musrenbang process experienced distortions (deviations) in its implementation, so took corrective steps. During the Musrenbang procedure, Information technology advancements are being used to solve Musrenbang problems related to development priorities. The development of an online application called e-Musrenbang is expected to answer general questions about the development planning process in their area and act as a liaison between the government and the community. Several major cities in Indonesia, including Medan, began implementing e-Musrenbang in the regional development system in 2017. Since 2017, domestically and internationally, has accessed eMusrenbang to learn which will implement programs and activities in the relevant year.

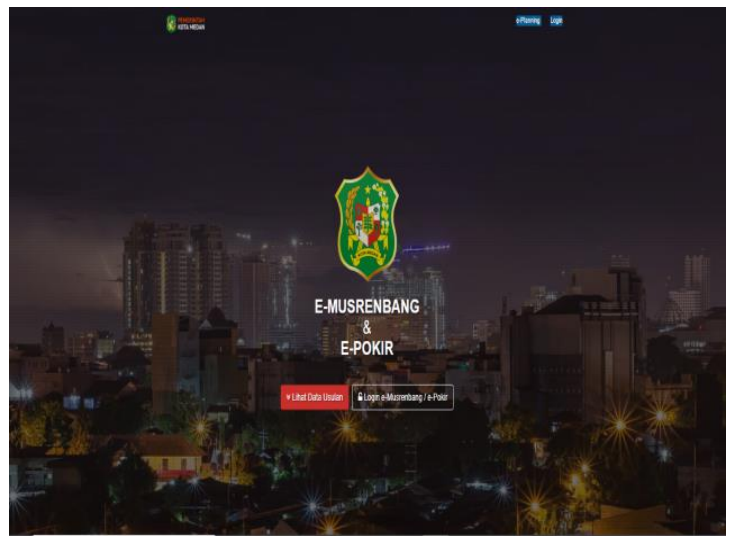

Figure 1. Medan City e-Musrenbang Portal page Source: BAPPEDA Medan City (2019)

Figure 1 is a page or display of the emusrembang website owned by the Medan City Government. 
Researchers are eager to learn whether e-Musrenbang has emerged as the best solution for regional development planning and improve this application's aspects to maximize its performance. Since the launch of the e-Musrenbang application, it has been implemented in all districts of Medan City, including the Medan Denai District, which has a high population density, piqued the interest of researchers. (Pemerintah Kota Medan, 2013). However, Medan Denai Sub-district has fewer activity proposal reports than other sub-districts in the Medan City eMusrenbang.

The Tegalsari Mandala II Village and the Binjai Village summarized most of the proposed activities in the e-Musrenbang provided by the Medan Denai District. According to the Medan City Central Statistics Agency (2020), the Binjai Village is the largest urban village in the Medan Denai District, with residents still complaining about the poor state of infrastructure. At the same time, the Tegalsari Mandala II village is the smallest in the Medan Denai District and is designated as a slum area by the Mayor of Medan. The determination of the location slum based development priorities which are housing and settlement units within the scope of Medan City, which considered unfit for habitation due to the irregularity of the building, the level of building density, the quality of the building, as well as facilities and infrastructure that do not meet the requirements. This is the reason the researcher chose this sub-district. This study aims to provide information about the weaknesses of the e-Musrenbang application implemented by the Medan Denai District as a recommendation for the Medan City government in making decisions regarding the improvement of the e-Musrenbang system so that the role and function of this application are getting better.

Based on the problems that have been described, this research focuses on the effectiveness of the implementation of eMusrenbang in the Regional Development Planning Process in Medan Denai District. Several studies, such as Yunas (2017), which examines the efficacy of eMusrenbang in the City of Surabaya in the development planning system, explain that e-Musrenbang can be an innovation in the development planning system in Indonesia, where people have traditionally desired a forum or social contact between citizens and the government in regional development planning.

Research from Ambarwati (2019), who studied participatory development planning in the implementation of eMusrenbang, stated that the performance of community participation in Musrenbang in Randudongkal District in 2019 was not optimal. This can be seen in the determination of regional program proposals. The sub-district head is left to determine program proposals even though the proposed program is not a village proposal. The participation that has been obtained so far in the village Musrenbang is meaningless and not adequately accommodated.

Nasution (2001) states that positioning communication in the context of development is an essential component of development and communication as a set of instrumental variables to achieve growth. All community activities and government efforts to fulfill the community's rights emphasize the importance of communication. The Musrenbang forum facilitates communication between the government and the community in conveying their aspirations for participatory development. Bessette (2004) argued that participatory development communication is a planned activity based on participatory processes on the one hand and the use of communication media and face-to-face communication on the other. The aim is to facilitate dialogue among different stakeholders, which revolves around 
formulating a common development problem or goal, developing and implementing or describing a set of activities that contribute to finding mutually supported solutions.

\section{RESEARCH METHOD}

This study used a descriptive research method with a qualitative approach, describing and summarizing various situations or variables in the research object about the conditions, concerns, or variables in this study. This study is being conducted in the Medan Denai District of Medan City.

The researcher wants to analyze the effectiveness of the e-Musrenbang by using the organizational effectiveness measurement proposed by Duncan (Steers \& Jamin, 2005). There are numerous measures of energy, all of which are based on the achievement of goals and objectives. The advantage of Duncan's effectiveness measurement is that it includes dimensions that explain whether the organization that implements the e-Musrenbang has successfully adapted to its use. Furthermore, the use of information technology necessitates the availability of qualified human resources. This is, of course, heavily emphasized to achieve the previously set goals and targets.

The technique of determining the informants is using the purposive sampling technique. According to Sugiyono (2013), purposive sampling is sampling data sources intentionally. Informants in this study are: 1) Key Informants; Head of Sub Division of Analysis and Reporting of the Regional Development Planning Agency (BAPPEDA) of Medan City, Community Leader 2) Main Informants: Village Operators in Medan Denai District, Medan City, Staff Staff of Medan Denai District; 4) Additional Informants; regional development expert.

This study uses two kinds of data collection techniques according to the type and source classification. First is the primary data collection technique, namely data obtained through research activities directly to the research location to find complete data related to the studied problem. This technique is carried out through the Interview Method (Interview) and Observation (Burhan, B, 2007).

The second is a secondary data collection technique which is a data collection technique carried out through library collection that can support primary data. Secondary data collection techniques can be done using Documentation Studies and Literature Studies (Suyanto, 2005).

The data analysis technique in this research is the qualitative data analysis technique. Data analysis was carried out when data collection took place using interviews and observations and after completing data collection within a certain period. Library data strengthen the analyzed data through books and regulations related to the problems in this research. Data analysis is carried out interactively and takes place continuously until complete until the data is saturated. Data analysis activities after data collection include data reduction, data presentation, and data verification (Sugiyono, 2013).

\section{RESULT AND DISCUSSION}

The authors limit the e-Musrenbang planning process in Medan City to implement the e-Musrenbang, namely in the development planning process in 2017, 2018, and 2019. The Mayor of Medan, HT Dzumi Eldin, stated that the goal of eMusrenbang is to make the planning process for Medan City development participatory, transparent, and accountable (Dinas Komunikasi dan Informasi Kota Medan, 2019). E-Musrenbang can emphasize the existence of Musrenbang as a bottom-up development planning process carried out from pre-Musrembang to Musrembang. It is hoped that the eMusrenbang, can provide concrete explanations and reasons for several programs that are not worthy of being 
included in development priorities in the development planning deliberation process.

The e-musrenbang system uses the data upload method that has been summarized from the Musrenbang process-starting from the lowest to the very top. The illustration can be seen in Figure 2.

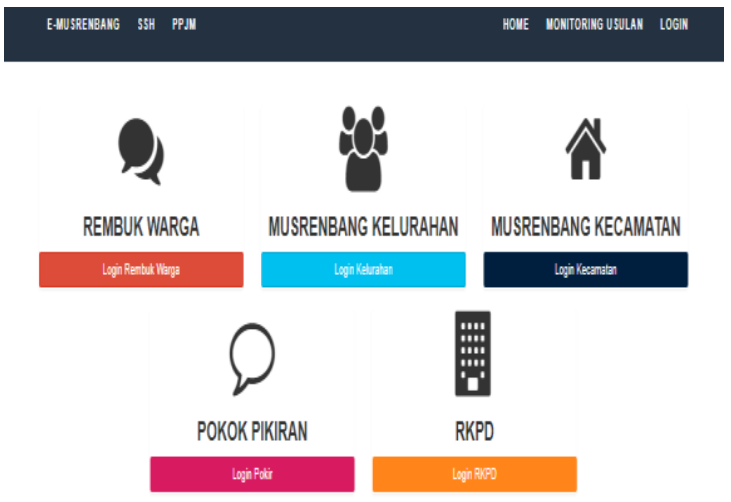

Figure 2. Stages of Regional Development Planning in e-musrenbang

Source: BAPPEDA Medan City (2019)

Figure 2 shows that the implementation of e-Musrenbang is not much different from the usual Musrenbang flow. The difference is that all evidence of the performance of Musrenbang activities can be seen, and we can view the things compiled in the meeting through the eMusrenbang website.

The Musrenbang activities must be documented and uploaded to the eMusrenbang system by the implementers involved. A significant difference is that there is a community consultation stage, which is the first stage that each region must carry out because it is intended that the data collected is valid by the community's aspirations so that it is by the main objectives in development planning, which requires developers to accommodate the interests of the community. Suryono (2001) It is important to emphasize that development begins with community participation. Community involvement in effect is regarded as critical because the development focus must accommodate the community's interests. This was also confirmed by the Medan City BAPPEDA's Head of Sub-division for Analysis and Reporting, who explained the differences between Musrenbang and e-Musrenbang implementation as follows: "The implementation of Musrenbang is based on Permendagri 86, at least starting from the village Musrenbang. Through this emusrenbang, the Medan City Government wants to reactivate community involvement limited so far. Therefore, the striking difference from the existence of the E-Musrenbang is that there is a Community Consultation stage as the first stage carried out in the current Musrenbang process."

With the existence of the eMusrenbang, the excerpt from the interview implies that community involvement is one of the goals of the Medan City Government. E-Musrenbang is a detailed reporting system that requires sub-districts to perform Musrenbang correctly and thoroughly. The reporting format is a proposed document and a list of attendees, accompanied by photos of the activity's implementation. Furthermore, a deadline for uploading data to the eMusrenbang application is set. This is done to prevent data manipulation or changes to previously agreed-upon proposals. Tegalsari Mandala II K's statement supports this: "The existence of the eMusrenbang is a good choice to improve the planning process, the things that are done in the Musrenbang process must be reported in detail and online so that the proposals reported are also fresh and directly from the community. As in the Community Consultation stage, this proposal is typed on the e-Musrenbang page directly".

The excerpt from the interview explains that with the e-Musrenbang, community involvement is more visible. The implementation of Musrenbang carried out the beginning year by dividing the time for the community consultation, which is carried out in every neighborhood in the village at the end of January. The time for 
the community consultation is ten days, followed by the Village Musrenbang stage. It is required to invite all neighborhood heads, community leaders, and the community for four days starting on February 5, 2019. On February 20, 2019, continued with the sub-district Musrenbang, which invited the village head, the head of the environment, the community, and presented Regional Apparatus Organizations (OPD). They were directly involved in proposed activities. To be discussed later.

The provisions that must be reported in the form of uploads and this deadline are a form of discipline for regional officials in accelerating the proposed activities, even though the Musrenbang process will continue to the city stage. "Reporting by the method offered by the e-Musrenbang shows the seriousness of the Regional and City Governments to be more responsive, of course, this data upload method can shorten the reporting time which is usually done manually," said the Head of Community Empowerment Development of Medan District Denai."

The upload reporting process like this can be an instrument for the Medan City Government to facilitate supervision in implementing the Musrenbang through the monitoring column available on the eMusrenbang page. Of course, this makes it a little difficult for the Medan City Government to carry out direct supervision regarding the validity of the data uploaded in the e-Musrenbang system. This refers to Situmorang's (1994) opinion, "The supervisory mechanism of an organization is necessary because it is a form of management function. Without an intensive and continuous monitoring system, a plan and program will run slowly and will not achieve the predetermined goals and objectives".

The e-Musrenbang forum application can be accessed at any time by anyone who wants to know the status of proposed activities that have been collected in the village and sub-district Musrenbang forums. The information presented is about the quality of the proposed action, whether it can realize it or not. If it cannot be discovered, the relevant OPD will provide a valid reason in the statement column of the proposal. More details can be seen in Figure 3:

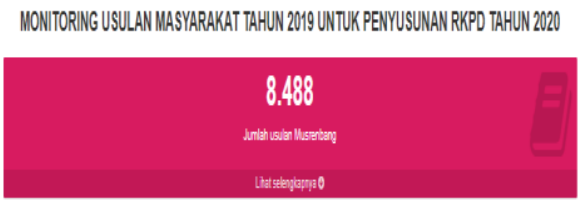

MONTORING USULAN MASYARAKAT TAHUN 2018 UNTUK PENYUSUNAN RKPD TAHUN 2019

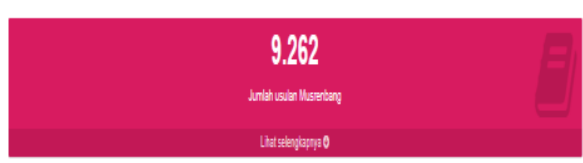

Figure 3. Main Thought Monitoring Source: BAPPEDA Medan City (2019)

Community involvement is a mandatory requirement in implementing eMusrenbang, especially the implementation reporting system, which must be accompanied by evidence of performance. Suryono (2001) explained that development begins with community participation. Community involvement in development is critical because the development focus must accommodate the community's interests. This confirms that the goal of e-Musrenbang is not only to provide a more controlled method for reporting proposals but also to allow the community's aspirations to be genuinely summarized based on the facts on the ground. The community's perspectives are also critical in assessing the existence of community consultations carried out as one of the stages of the e-Musrenbang. Tegalsari Mandala II Village consists of 15 Neighborhoods, and Binjai Village consists of 20 Neighborhoods that have participated in the implementation of the Community Consultation.

Tegalsari Mandala II Village's neighborhoods have all conducted effective 
community consultations. According to the e-Musrenbang operator in Tegalsari Mandala II Village, the community was very excited about the community consultation. The implementation of community consultations held near residents' homes, of course, makes participation easier for them. The main goal, of course, is to become acquainted with the residents. "The community is very enthusiastic and feels very helpful in expressing their aspirations," said the operator of Kelurahan Tegalsari Mandala II. In addition, the eMusrenbang system builds public trust through the method of reporting every detail of the implementation through photos so that people have more confidence compared to the previous performance."

Because residents' consultations were held in the Musrenbang's ward before the existence of the e-Musrenbang, maintained the interaction between the ward Government and residents. "Before the eMusrenbang system was introduced, the Community Consultation had been carried out because, in the planning process, the residents had to directly meet with the residents to find out what the residents needed," said the Operator of Binjai Village, Medan Denai Sub-district.

Uniting every interest and changing people's desires in every development plan is not easy. There are still many people who do not understand well their role in development planning. As long as this continues, participation will only be seen as a participatory formality, while the actual reality is hegemony and manipulation (Abe, 2002). Community participation in development must be one of the main factors and the government as the executor. Conyers (1991) explains three reasons for the importance of community participation in development, namely: first, community participation is a tool to obtain information related to the conditions, desires, and attitudes of the community. Both communities will have more confidence in the development program if they are involved in the planning process. The three districts have democratic rights so that they must be included in the development process itself. The implementation of the eMusrenbang is expected to answer the fulfillment of this democratic right. The fact is that in the field, there is still community dissatisfaction with the performance of the Musrenbang even though the eMusrenbang has been present. Implementation in Tegalsari Mandala II Village, the existence of e-Musrenbang is still not felt significantly. The following are excerpts from interviews with the Head of Environment 10 in Kelurahan Tegalsari Mandala II and the community that the author can summarize.

The Head of Environment 10, Kelurahan Tegalsari Mandala II, said, "I don't feel any difference in the implementation of the Musrenbang before or after the e-Musrenbang. I've been ahead of the ward in Ward 10 for six years, which means I've been through both systems. The number of proposed activities that we have discussed has not yet been realized. The activities that we propose every year always sound the same: improving drainage, repairing roads, and increasing the number of electricity poles for lighting. Until now, the flood continues to inundate this neighbourhood ten roads if it rains heavily".

The interview results explained a discrepancy in the statements regarding the residents' enthusiasm for participating in the community consultation process.

The form of communication that can be done by the government related to development is by conducting socialization. Socialization is carried out to the relevant implementers as the key to successful implementation and the community as the primary development target.

Budiman (2016) According to his research findings, the government's development communication pattern does not provide enough space for stakeholders 
to participate in the entire communication process, beginning with planning, organizing, implementing, and monitoring.

Tegalsari, Mandala II Village community, does not feel involved in the eMusrenbang system; therefore, the government must immediately evaluate. The lack of socialization or introduction to the e-Musrenbang system causes residents not to understand the systematics. This was conveyed by a resident of 11 Tegalsari Mandala II Kelurahan who said: "We have never heard or received direct invitations from the implementation of the Community Consultation, Village Musrenbang or Musrenbang at the sub-district level. So far, what I know of such a thing is that only certain people are involved in it."

The author's field observations, every stage of the activity in the e-Musrenbang before it is implemented, the head of the environment issues an invitation issued by the agency or authorized to carry it out. Residents should have received the invitation a week before the e-Musrenbang stage to accumulate citizen participation in the planning process.

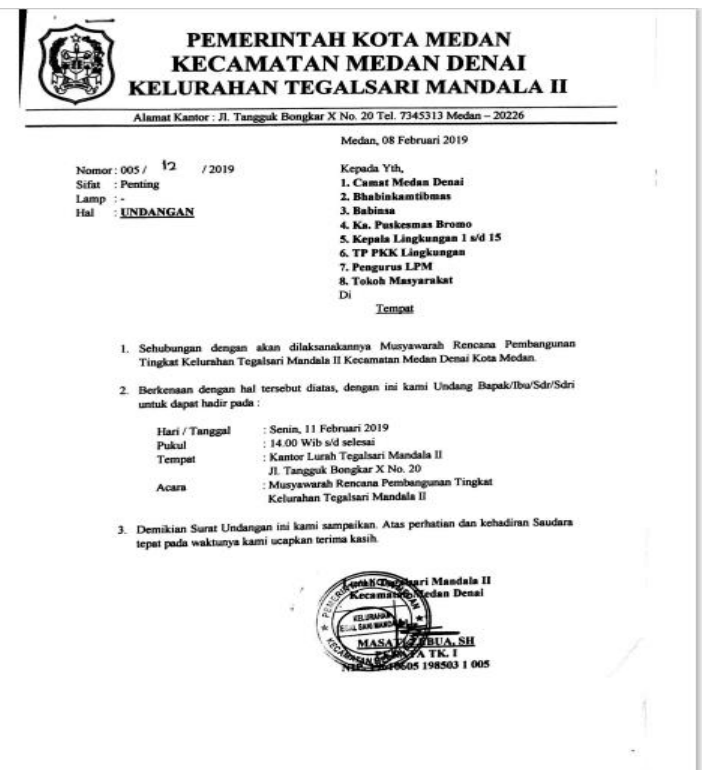

Figure 4. Invitation to Musrembang Village of Tegalsari Mandal II

Source: Tegalsari Mandala II Village Head Office (2019)

The invitation is attached to the eMusrenbang system as evidence of the implementation of the Village Musrenbang. Still, in reality, the residents of Tegalsari Mandala II stated that they did not know the planning process was carried out. The communication pattern only runs in one direction, and the Village Government does not get community participation in designing programs or activities to be implemented. Aminah et al. (2019) argued that the lack of community participation in development communication resulted in not yet maximal communication between the government and the community.

There is a need for modernization or a change in the relationship between the village government and residents so that the perception of equality in the development planning process can run as it should. Koentjaraningrat (Effendi, 2004) states that can carry out modernization by providing examples, persuasion, information, and education. Giving examples, influence, news, and education will take place through the communication process. Sulistiani et al. (2017) emphasize that the public's ignorance of the importance of deliberation is the cause of the lack of community participation.

All stages in the e-Musrenbang in its implementation must include evidence of activities that have been carried out, then uploaded to the e-Musrenbang system. It is not difficult to manipulate the requested data, as stated by the Head of Environment 2 Kelurahan Binjai, who said: "Whether or not there is a Community Consultation, actually residents have resigned themselves to the development being carried out because often the proposed program or activity is not implemented. So the implementation of the Citizen Meeting which must be uploaded, I have to make it look like it is being carried out properly."

The transcript from the interview is supported by a statement from Tegalsari Mandala II ward's Head of Environment 10, who stated: "At the community consultation activity, which does not produce the programs needed by the 
community every year, it makes the community reluctant to attend the same activity." While the implementation of activities must continue, it is not uncommon for me to provide the lure of consumption for people to attend; the most important thing is that photos of the gathering with residents have been obtained. It's a matter of whether activities are carried out following or not."

The following is an example of a photo of the implementation of the community discussion carried out by the Tegalsari Mandala II Village.

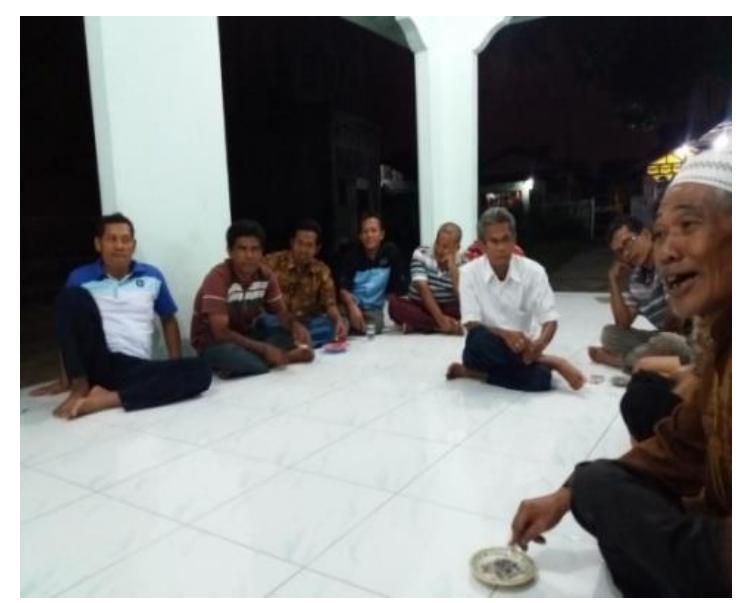

Figure 5. Discussion of Community Residents of 10 Tegalsari Mandala II Villages Source: BAPPEDA Medan City 2019

Figure 4 is obtained from the eMusrenbang system and shows that the residents of Neighborhood 10 Kelurahan Tegalsari Mandala II voluntarily sit together to listen to and correct proposed activities for the construction of inadequate infrastructure in their neighborhood.

Aside from the Musrenbang process, which did not follow the proper procedure, the authors discovered that each proposal must be accompanied by a state of facts on the ground, as shown in Figures 6 and 7.

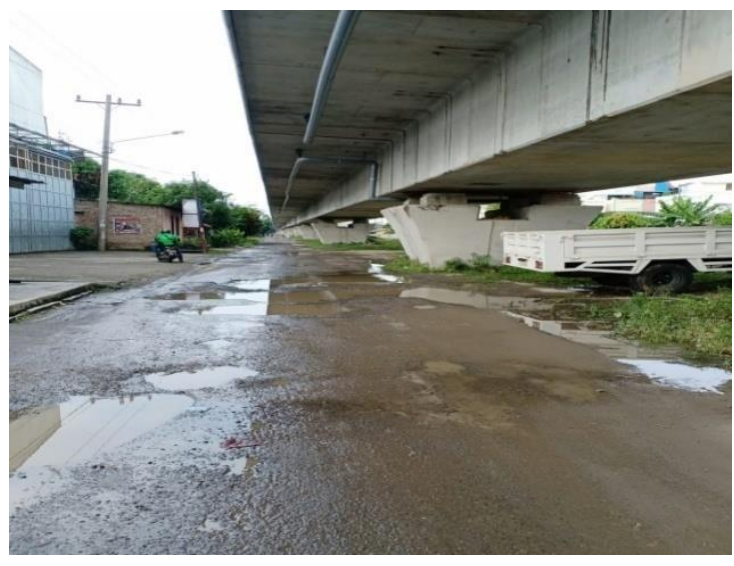

Figure 6. The Condition of Binjai Village Road, which is Severely Damaged Source: BAPPEDA Medan City (2019)

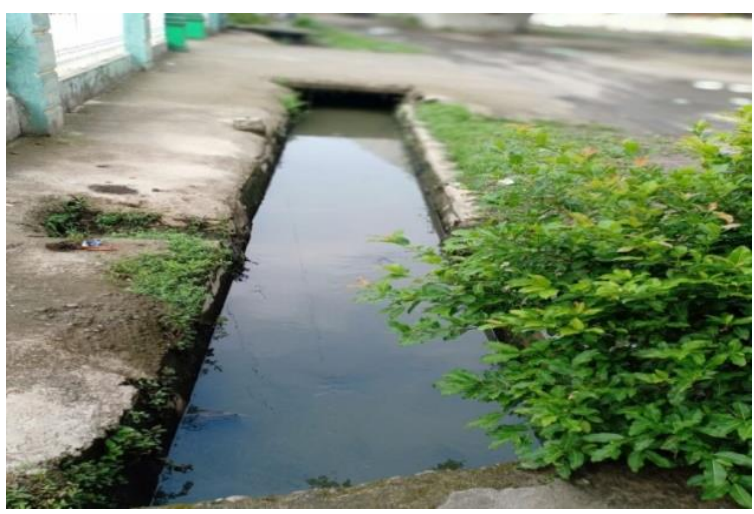

Figure 7. Drainage Condition of Tegalsari Mandala II Village

Source: BAPPEDA Medan City (2019)

The data attached to the eMusrenbang makes it much easier for relevant regional apparatus organizations to assess the condition of infrastructure to be taken into consideration in determining the priority scale of development to be implemented. Program Kota Tanpa Kumuh (KOTAKU) Medan City with several related agencies, as the Sanitation Department and the Public Works Department served as the primary implementers to carry out these activities. The author discovered information confusion regarding proposed activities that were not implemented, specifically the monitoring of eMusrenbang, which only attached a statement stating that the location data entered as a proposal had not been fulfilled 
or had not met the requirements as development priorities. The problem is that not all residents understand the limitations of activities that can realize according to the priority scale. Can assess citizen involvement as still minimal since the formulation of development activities. According to Abe (2002), the principle of involving the community directly by "involving the interests of the community" is only possible if the community itself takes part from the beginning, the process, and formulation of the results of development planning. The involvement of the people will be the guarantor for a good and correct approach.

Based on the author's observation, the adaptation factor in the effectiveness of the e-Musrenbang in Medan City. According to Denison \& Mishra (1995), adaptation emphasizes the organization's ability to accept, interpret, and translate disturbances from the external environment into internal norms that lead to survival or success. to internal and external customers. The ability of the implementers, namely the operators at each layer of the e-Musrenbang stages, to adapt to the facilities used to support the implementation of e-Musrenbang, such as the use of information technology, is referred to in this study. The ability of the implementers, namely the operators at each layer of the e-Musrenbang stages, to adapt to the facilities used to support the implementation of e-Musrenbang, such as the use of information technology, is referred to in this study.

According to the Head of the Medan City BAPPEDA's Sub-department for Analysis and Reporting, to anticipate the existence of this capability discrepancy, the Medan City BAPPEDA provided training to all operators in the Medan Denai Village and District to provide direction or equalize perceptions in implementation to reduce errors in data uploading. The documentation of the training implementation carried out by the Medan City BAPPEDA is provided below:

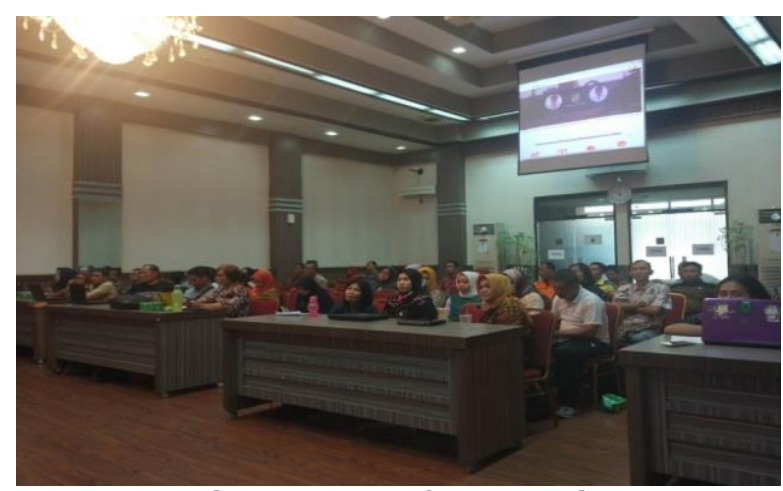

Figure 8. Implementation of e-Musrenbang training Source: BAPPEDA Medan City (2019)

The training is carried out only once a year. Wexley and Yulk (Mangkunegara, 2009) argue that development and training are matters relating to planned efforts carried out to realize an understanding of the skills, knowledge, and attitudes of employees or members of the organization and explain that training and development are matters relating to planned efforts carried out to achieve mastery of skills, knowledge, and attitudes of employees or members of the organization Development is more concerned with improving decision-making and interpersonal skills.

Based on the interviews, the authors found that the training provided was still very minimal to equalize the abilities of all operators. Several villages or sub-districts do not meet the data uploaded in the eMusrenbang system, Binjai Village, Medan Denai District, and Medan Denai District (https://eplanning.pemkomedan.go.id/ep erencanaan/web/ accessed September 6, 2019). This implies that there is no supervision from the Medan City BAPPEDA regarding the implementation of the Musrenbang and the operation of the eMusrenbang in sub-districts and subdistricts. The e-Musrenbang page that every ward and sub-district must fill in after carrying out the Musrenbang is empty because the data should consist of photos of activities, letters invitations, and attendance lists that can upload e- 
Musrenbang system although they are not complete. Lack of infrastructure is one of the inhibiting factors, one of which is the availability of an inadequate internet network at the Musrenbang implementation site. The ward often uses the internet network from privately owned cell phones. This can be seen from the statement of the Tegalsari Madala II Kelurahan operator who said: "The training was carried out only once at the beginning of the e-Musrenbang implementation year so that many operators in the ward still did not understand, regardless of the operator changes. In addition, what is very unfortunate is that there is no complete infrastructure such as internet access or modems provided. We have to work on this ourselves if we don't want to; however, the data input must be running and on time according to the assignment letter given."

"Training was given in the first year the e-Musrenbang system was introduced, and there will be more training in 2019 regarding system changes," said the Binjai Village operator."

Based on the excerpt from the interview, we can conclude that the organization's readiness to implement eMusrenbang is still far from complete. Minimal internet access is one of the essential tools in this regard. It is not uncommon for implementers or operators to use personal funds to purchase a modem to input data into the e-Musrenbang system.

\section{ACKNOWLEDGMENTS}

The researchers thank the Research Institute of Universitas Sumatra Utara, which has provided research funds to carry out this research properly and published it.

\section{CONCLUSION}

Since 2017, the e-Musrenbang has been in operation. During the implementation period, the effectiveness of the e-Musrenbang system in Medan Denai District was deemed to be less than optimal.
The aspirations of the Medan Denai Subdistrict residents have not been fully accommodated, and many residents claim to be unaware of this e-Musrenbang system. Similar to the implementation of the Musrenbang, in the performance of the e-Musrenbang, the large number of activities proposed by the community and the environmental head were not realized, making the community bored and reluctant to participate in this forum. Citizens' misunderstanding in the e-Musrenbang system is seen as a lack of good communication or socialization between the government and its citizens. Found that the ward and Medan Denai Subdistrict Governments as implementers in using the e-Musrenbang system were still rigid and did not understand the use of the eMusrenbang system properly.

\section{REFERENCES}

Abe, A. (2002). Perencanaan Daerah Partisipatif. Solo: Pondok Edukasi.

Adisasmita, R. (2006). Pembangunan pedesaan dan perkotaan. Yogyakarta: Graha Ilmu.

Ambarwati, I. D. (2019). Perencanaan Yang Tak Partisipatif: Proses Musyawarah Perencanaan Pembangunan (Musrenbang) Kecamatan Randudongkal Kabupaten Pemalang Tahun 2019. Jurnal Penelitian Universitas Diponegoro, 1-8.

Aminah, S., Sumardjo, N., Satria, A., \& Abdullah, I. (2019). Partisipasi Masyarakat Pesisir Dalam Komunikasi Pembangunan Di Perbatasan Antarnegara. Jurnal Pikom (Penelitian Komunikasi Dan Pembangunan), 20(1), 29. https://doi.org/10.31346/jpikom.v20i1.177 9

Aziz, B, dan Khairul, M. (2012). Analisis Perencanaan Pembangunan Daerah Dengan Pendekatan Sistem Lunak (Soft System) (Studi Pada Rencana Kerja Pembangunan Daerah (RKPD) Kota Malang). Jurnal Administrasi Publik (JAP), 13(2), 1930-1936.

Bessette, G. (2004). Involving the Community: A Guide to Participatory Development Communication. Jutaprint: Penang, Malaysia.

Budiman. (2016). Pembangunan Pusat Layanan Internet Kecamatan Dalam Sistem Komunikasi Pembangunan Daerah: Kasus Di Kabupaten Simeulue - Aceh. Jurnal Pikom (Penelitian Komunikasi Dan Pembangunan), 17(1), 41. 
Siti Hazzah Nur Ritonga \& Humaizi, E-Effectiveness Musrembang's in the Development Planning Process

Bungin, B. (2007). Penelitian Kualitatif: Komunikasi, Ekonomi, Kebijakan Publik, dan Ilmu Sosial Lainnya. Jakarta: Kencana.

Carlson, N. R. (2007). Psychology, the Science of Behavior, sixth edition. United States of America: Pearson Education Inc.

Conyers, D. (1991). Perencaan Sosial di Dunia Ketiga. Yogyakarta: Gajah Mada University Press.

Dan, S., \& Juhir. (1994). Manajemen Sumber Daya Manusia. Bandung Pustaka Setia.

Denison, D. R., \& Mishra, A. K. (1995). Theory Org Culture Effectiveness. Organization Science, 6(2), 204-223.

Effendi, O. U. (2004). Dinamika Komunikasai. Bandung. Bandung: Remaja Rosdakarya, 2008.

Kota Medan, P. (2013). Kependudukan. https://pemkomedan.go.id/halkependudukan.html

Mangkunegara, A. P. (2009). Evaluasi Kinerja Sumber Daya Manusia. Bandung: Penerbit Refika Aditama.

Medanbicara.com. (2019). Ini Target Walikota Medan Dzulmi Eldin di Musrenbang 2020. https://medanbicara.com/medan/initarget-walikota-medan-dzulmi-eldin-dimusrenbang- 2020

Medanposonline.com.(2020).Warga Medan Denai Masih Keluhkan Infrastruktur. https://medanposonline.com/seputarmedan/warga-medan-denai-masihkeluhkan-infrastruktur/

Miles, M.B, Huberman, A.M, dan Saldana, J. (2014). Qualitative Data Analysis, E Methods Sourcebook (Terje). Edition 3. USA: Sage Publications. Terjemahan Tjetjep Rohindi Rohidi, UI-Press.
Moleong, L. (2002). Metodologi Penelitian Kualitatif. Bandung: PT. remaja Rosdakarya.

Nasution, Z. (2001). Komunikasi Pembangunan. Pengenalan Teori dan Penerapannya (Ed. Rev). Jakarta : Raja Grafindo Persada.

Setianingsih, B. (2015). Efektivitas Sistem Perencanaan Pembangunan Daerah (Simrenda) (Studi Pada Badan Perencanaan Pembangunan Daerah Kota Malang). Jurnal Administrasi Publik Mahasiswa Universitas Brawijaya, 3(11), 1930-1936.

Steers, R. M., \& Jamin, M. (2005). Efektivitas organisasi (Terj). Jakarta: Erlangga.

Sugiyono. (2013). Metode Penelitian Kuantitatif, Kualitatif dan $R$ \& D. Bandung: CV. Alfabeta

Sulistiani, I., Sumardjo, Purnaningsih, N., \& Sugihen, B. G. (2017). Peran Komunikasi Dalam Pengembangan Energi Sosial Masyarakat Di Papua. Jurnal Pikom (Penelitian Komunikasi Dan Pembangunan), 18(1), 43-56.

Suryono, A. (2001). Teori dan Isu Pembangunan/Agus Suryono. Universitas Negeri Malang (UM Press).

Suyanto, B. (2005). Metode Penelitian Sosial Berbagai Alternatif Pendekatan. Jakarta: Prenada

Tresiana, N., \& Duadji, N. (2016). Kegagalan pemaknaan "Lembaga Musawarah Perencanaan dan Pembangunan Desa"dalam mewujudkan deepening democracy. Masyarakat, Kebudayaan Dan Politik, 29(4), 191.

Yunas, N. S. (2017). Efektivitas E-Musrenbang di Kota Surabaya dalam Sistem Perencanaan Pembangunan Berparadigma Masyarakat. Otoritas : Jurnal Ilmu Pemerintahan, 7(1), 19. 